\title{
Stable carbon isotope compositions of isoprenoid chromans in Cenozoic saline lacustrine source rocks from the Western Qaidam Basin, NW China: Source implications
}

\author{
ZHANG YongDong ${ }^{1,3}$, JIANG AiZhu $^{1,3}$, SUN YongGe ${ }^{1,2^{*}}$, XIE LiuJuan ${ }^{2}$ \& CHAI PingXia ${ }^{1}$ \\ ${ }^{1}$ State Key Laboratory of Organic Geochemistry, Guangzhou Institute of Geochemistry, Chinese Academy of Sciences, \\ Guangzhou 510640, China: \\ ${ }^{2}$ Department of Earth Science, Zhejiang University, Hangzhou 310027, China; \\ ${ }^{3}$ Graduate University, Chinese Academy of Sciences, Beijing 100049, China
}

Received August 29, 2011; accepted November 4, 2011; published online December 14, 2011

\begin{abstract}
Although the distribution of mono-, di- and trimethylated 2-methyl-2-(4,8,12-Trimethyltrideeyl) chromans (MTTCs) is well understood as an indicator of water salinity, their origin and formation mechanism are still ambiguous and under debate. In this paper, abnormally high levels of MTTCs were detected in Cenozoic saline lacustrine source rocks from the Western Qaidam Basin. Using a two-step column chromatography method, the MTTCs and naphthalenes were separated from other aromatic compounds and concentrated in one fraction, so that the stable carbon isotope compositions of these compounds could be accurately measured. Similar carbon isotope ratios for the mono-, di- and trimethylated 2-methyl-2-(4,8,12-Trimethyltrideeyl) chromans in a given sample suggest the MTTCs may share the same biological source(s). The MTTCs from the Western Qaidam Basin have similar carbon isotope compositions to primary producer-derived pristane and phytane. However, the $\delta^{13} \mathrm{C}$ values for the MTTCs showed significant differences with other primary producers-derived biomarkers (e.g. $\mathrm{C}_{27}$ and $\mathrm{C}_{29}$ steranes), probably indicating a distinct microalgae source from specific niches for the MTTC compounds. We speculate that the MTTCs distribution patterns may be controlled by the water chemistry dynamics in niches, which, in turn, is affected by hypersaline bottom water.
\end{abstract}

saline lacustrine source rocks, MTTCs, stable carbon isotope composition, microalgae, Qaidam Basin

Citation: Zhang Y D, Jiang A Z, Sun Y G, et al. Stable carbon isotope compositions of isoprenoid chromans in Cenozoic saline lacustrine source rocks from the Western Qaidam Basin, NW China: Source implications. Chin Sci Bull, 2012, 57: 1013-1023, doi: 10.1007/s11434-011-4899-8

Aromatic hydrocarbons are one of the most important fractions in soluble sedimentary organic matter, although they are less used in organic geochemistry than aliphatic fractions because of their complexity in terms of source, diagenetic processes, and secondary alterations. However, aromatic compounds with distinct biological precursors or related to thermal process (e.g. aromatic terpenoids from higher plants, aromatic steroids, methyl-phenanthrene, alkylated naphthalene, and aromatic isoprenoids compounds), have been widely used as indicators of organic source, depositional environments and the thermal maturity of organic matter. In particular, a series of methylated isoprenoid

*Corresponding author (email: ygsun@zju.edu.cn) chroman compounds (methylated 2-methyl-2-(4,8,12trimethyltridecyl) chromans (MTTCs)) present in aromatic fractions, have been given considerable attention because of their application to water paleosalinity evaluation [1-10]. The MTTCs can be regarded as dehydroxy products of tocopherol. Based on the number of methyl groups on the aromatic ring, the three main MTTC compounds are 8-methylMTTC ( $\delta$-MTTC), 7,8-dimethyl-MTTC ( $\gamma$-MTTC), and 5,7,8-trimethyl-MTTC ( $\alpha$-MTTC). Previous studies showed that the distribution patterns of these MTTC compounds can be indicative of water paleosalinity during the source rock deposition. In hypersaline settings, $\delta$-MTTC tends to dominate, whereas $\alpha$-MTTC is more abundant than other MTTC compounds in normal salinity settings [4-7]. Although the 
relationship between the MTTCs distribution and water paleosalinity has been verified by other geochemical data, it is still an experienced judgment for the MTTCs salinity indicator because the biological source of MTTCs and the processes involved in their diagenetic transformation are still unclear [6].

Although methylated MTTCs are structurally related to tocopherol, they are unlikely to originate from tocopherol during diagenesis on chemical grounds [2]. Sinninghe Damsté et al. [2] found abundant $\delta$-MTTC in a stratified hypersaline water body, and initially ascribed non photosynthetic bacteria as the biological sources of MTTCs. After further investigation, Sinninghe Damsté et al. [6] provided an alternative suggestion of photosynthetic organisms in the upper part of the water column as the sources of MTTCs based on a molecular geochemistry study of organic matter from marl in the Oligocene Mulhouse Basin. In particular, the similarity in stable carbon isotope values between MTTCs and photosynthetic organism biomarkers were used as evidence for this source. Further evidence supporting the photosynthetic organism source of MTTCs was also provided by Grice et al. and Lu et al. [11-13]. A further study by Van Kaam-Peters and Sinninghe Damsté [14] revealed another potential source for MTTCs: photosynthetic bacteria via the Calvin cycle; which was evidenced by the molecular distributions and stable carbon isotope compositions of MTTCs and other biomarkers. In contrast to the results reported by the Sinninghe Damsté group, Li et al. [8] suggested that the MTTCs may be derived from condensation of alkylphenols and phytol from chlorophyll during diagenesis, and this was supported by the chemical synthetic routes of the artificial MTTCs. The problem associated with this hypothesis is that there are limited numbers of structural isomers of MTTCs in geological setting, and consequently, this hypothesis is less attractive [9]. Therefore, the sources of MTTCs in sediments are still unclear.

The Oligocene source rocks of Western Qaidam Basin are typical saline lacustrine deposits, with significant amounts of MTTC compounds detected [15]. In general, the source rock depositional environments and biological inputs in this study are consistent with previously reported saline lacustrine deposits $[15,16]$. The biomarker assembles and molecular stable carbon isotope compositions change considerably through the profile, as do the special biomarkers detected, such as highly branched isoprenoids with 25 carbon atoms $\left(\mathrm{C}_{25} \mathrm{HBI}\right)$, which may be related to the diatom blooms and highly reducing conditions [16]. This study focused on the sources of MTTCs and factors controlling the distributions and stable carbon isotope compositions of MTTCs in sedimentary organic matter.

\section{Samples and experimental}

Six core samples of calcareous mudstone were collected between 2831 and $3056 \mathrm{~m}$ from well Yuehui-103 in the Western Qaidam Basin, NW China. The samples were collected within the Oligocene Upper Section of the Lower Ganchaigou Formation. The location of the well is described in the published literature [17]. The six samples were numbered as CDM1 to CDM6 from the top to the bottom (Table 1).

The core samples were ground into powder, and used to determine total organic carbon (TOC) content, and to conduct Rock-Eval pyrolysis analyses. About $100 \mathrm{~g}$ of powered sample was extracted with dichloromethane and methanol (97:3) for $72 \mathrm{~h}$ in a Soxhlet apparatus. The asphaltenes were removed from the extracted organic matter by precipitation with petroleum ether, followed by filtration. The deasphaltened extracts were then separated into aliphatic, aromatic and polar (NSO) fractions by column chromatography. The column was packed with a mixture of preactivated silica gel and alumina $(9: 1, \mathrm{v} / \mathrm{v})$, and eluted sequentially with petroleum ether, benzene, and ethanol, respectively, for the three fractions.

To measure the carbon isotope compositions of MTTC compounds accurately, the MTTCs were separated from the aromatic fractions by two step column chromatography. Alumina was packed in the column as the stationary phase, with petroleum ether and dichloromethane as the solvents. The aromatic fraction was eluted into a monoaromatic sub-fraction (defined as A1), a diaromatic sub-fraction (defined as A2), and a triaromatic sub-fraction (defined as A3) with increasing polarity of the solvents [18]. The MTTC compounds are concentrated in the A2 sub-fractions. After the two step column chromatography separation, the concentration of the unresolved complex mixture (UCM) compounds is greatly decreased in the A2 fraction, so the carbon

Table 1 TOC values and mineral compositions (\%) of source rocks in this study

\begin{tabular}{|c|c|c|c|c|c|c|c|c|c|c|c|c|}
\hline Sample No. & Depth $(\mathrm{m})$ & TOC $(\%)$ & Montmorillonite $^{a}$ & Illite & Quartz & Feldspar & Calcite & Dolomite & Chlorite & Pyrite & Analcite & Others \\
\hline CDM1 & 2831.6 & 1.07 & 13.7 & 17.2 & 12.7 & 11.8 & 22.5 & 12.3 & 4.2 & 2.7 & 1 & Gypsum 2 \\
\hline CDM2 & 2845.32 & 3.52 & 19.9 & 20 & 16.8 & 13 & 7.8 & 7.2 & 6.7 & 4.9 & 2.2 & Gypsum 1.6 \\
\hline CDM3 & 3018.14 & 2.69 & 16.3 & 20.3 & 15.9 & 14.7 & 6.1 & 12.2 & 9.3 & 3.3 & 1.8 & \\
\hline CDM4 & 3022.16 & 2.13 & 13.3 & 21.7 & 14.9 & 15.1 & 7.3 & 13.6 & 9.6 & 3.5 & 1 & \\
\hline CDM5 & 3043.77 & 2.37 & 10.6 & 14.5 & 11.3 & 12.5 & 16.5 & 14 & 9.6 & & 1 & Anhydrite 10.1 \\
\hline
\end{tabular}

a) The mineral compositions of rocks were determined by X-Ray diffraction (\%). 
isotope compositions of MTTCs can be accurately determined. To evaluate the influence of residual UCM compounds on the MTTCs carbon isotope determination, $n$-alkanes mixtures with known $\delta^{13} \mathrm{C}$ values were added to the A2 fraction of some samples, and then compound specific carbon isotope analyses were conducted. The alkane $n-\mathrm{C}_{25}$ has a similar retention time to the MTTCs during GC-IR-MS analysis, and the differences in the $\delta^{13} \mathrm{C}_{n \text {-C25 }}$ values between the measured value and the standard value was less than $0.5 \%$. Therefore the UCM compounds in the A2 fraction do not have much influence on the MTTCs carbon isotope analysis.

Gas chromatography-mass spectrometry (GC-MS): The A2 aromatic hydrocarbon sub-fraction was analyzed by gas chromatography mass spectrometry (GC-MS) using a Thermo Scientific DSQ II mass spectrometer coupled to a Thermo Scientific Trace gas chromatograph. The chromatographic separation was achieved on a $60 \mathrm{~m} \times 0.32 \mathrm{~mm}$ i.d. fused silica capillary column coated with a $0.25 \mu \mathrm{m}$ film of DB-1. The oven temperature program started at $80^{\circ} \mathrm{C}(2$ $\mathrm{min}$ ), and then increased from 80 to $310^{\circ} \mathrm{C}$ at $3^{\circ} \mathrm{C} / \mathrm{min}$. This final temperature was maintained for $30 \mathrm{~min}$. Helium was used as the carrier gas with a flow rate of $1.2 \mathrm{~mL} / \mathrm{min}$. The ion source temperature was $250^{\circ} \mathrm{C}$. The ion source was operated in the electron impact (EI) mode at $70 \mathrm{eV}$. The full scanning mode was used.

Gas chromatography-isotopic ratio mass spectrometry (GC-IR-MS): The stable carbon isotope analyses of the A2 aromatic hydrocarbon sub-fraction were performed on a GV Isoprime system interfaced to a Hewlett-Packard 6890 gas chromatograph. The GC was fitted with a $60 \mathrm{~m} \times 0.32 \mathrm{~mm}$ i.d. DB-1 fused silica capillary column with a film thickness of $0.25 \mu \mathrm{m}$, leading directly into the combustion furnace. The oven temperature program started at $80^{\circ} \mathrm{C}(2 \mathrm{~min})$, and then increased from $80^{\circ} \mathrm{C}$ to $310^{\circ} \mathrm{C}$ at $3^{\circ} \mathrm{C} / \mathrm{min}$, remaining at $310^{\circ} \mathrm{C}$ for $10 \mathrm{~min}$. Helium was used as the carrier gas. The isotopic values were calibrated against a reference gas, and are reported in the usual "delta" notation relative to VPDB. The precision of the measurements was typically < $0.5 \%$. The accuracy of the instrument was tested two to three times daily, by analyzing a mixture of $n$-alkanes with known $\delta^{13} \mathrm{C}$ values acquired from Indiana University.

\section{Results and discussion}

\subsection{Bulk geochemical characteristics of source rocks and identification of MTTC compounds}

The bulk geochemical characteristics of the source rocks have been previously reported in detail $[16,17]$. Briefly, the six calcareous mudstone and marl samples were collected from the Oligocene Upper Section of the Lower Ganchaigou Formation in the Western Qaidam Basin. The RockEval $T_{\max }$ values of the six source rocks all were below $435^{\circ} \mathrm{C}$, and the $\mathrm{C}_{29} 5 \alpha(\mathrm{H}), 14 \alpha(\mathrm{H}), 17 \alpha(\mathrm{H})$-sterane $20 \mathrm{~S} /$
$(20 \mathrm{~S}+20 \mathrm{R})$ ratios were all $<0.3$, indicating a marginally mature level and little thermal influence on the biogeochemical information derived from sedimentary organic matter. All six samples can be classified as type II kerogen due to the high TOC and hydrogen index (HI) values, particularly for the four middle samples (CDM2 to CDM5), which come from source rocks with good hydrocarbon production potential.

The molecular geochemical characteristics of the six samples had similar patterns to other saline lacustrine source rocks, as follows. The relative concentrations of phytane, gammacerane and steranes are abnormally high, while the hopanes have relatively low concentrations. The $n$-alkane distributions usually show an even-odd carbon predominance in the $n-\mathrm{C}_{21}$ to $n-\mathrm{C}_{29}$ range with the highest peak at $n-\mathrm{C}_{20}$ or $n-\mathrm{C}_{22}$. Abundant concentrations of highly branched isoprenoids with 25 carbon atoms $\left(\mathrm{C}_{25} \mathrm{HBI}\right)$ were detected in the three middle samples (CDM3 to CDM5), indicating diatom inputs to the sedimentary organic matter [16].

Using traditional column chromatography technology, the MTTC compounds are usually detected in the aromatic fractions [19]. We recently developed a two-step column chromatography separation method for the aromatic fractions, which allows the MTTC compounds to be enriched in the $\mathrm{A} 2$ aromatic sub-fraction together with naphthalenes [18] (Figure 1). In the total ion chromatography (TIC) of the A2 fraction, the GC retention time of MTTCs on a DB-1 stationary phase lies between the naphthalenes and the triaromatic steranes, showing a good separation from other compounds. The new separation procedure also largely decrease the UCM content in the A2 fraction, with most of the UCM compounds found in the monoaromatic fractions (A1) and the resides fraction (A3), making it possible to accurately determine the stable carbon isotope values of MTTCs.

The identification of the MTTC compounds was undertaken by comparing the mass spectra with published mass spectrometry characteristics for MTTCs (Figure 2) [2,19]. The main mass fragments of $\delta$-MTTC were $m / z, 121,161$, $386\left(\mathrm{M}^{+}\right), 371\left(\mathrm{M}^{+}-15\right)$, and $343\left(\mathrm{M}^{+}-43\right)$. The main mass fragments of $\gamma$-MTTC were $m / z 135,175,400\left(\mathbf{M}^{+}\right), 385$ $\left(\mathrm{M}^{+}-15\right)$ and $357\left(\mathrm{M}^{+}-43\right)$; and the main mass fragments of $\alpha$-MTTC were 149, 189, $414\left(\mathrm{M}^{+}\right), 399\left(\mathrm{M}^{+}-15\right)$ and 371 $\left(\mathrm{M}^{+}-43\right)$. As shown in Figure $1, \delta$-MTTC was the most abundant MTTC compounds in the TICs of the $\mathrm{A} 2$ aromatic sub-fraction, with relatively low abundances of $\gamma$-MTTC and $\alpha$-MTTC. The $\alpha$-MTTC $/ \delta$-MTTC values for all six samples are lower than 0.3 (Table 2), which is consistent with other saline lacustrine deposits [2,5-7].

\subsection{Distributions and geochemical significance of MTTC compounds}

The aromatic fraction accounts for approximately $4 \%$ to $10 \%$ of the total extracted organic matter in the studied 


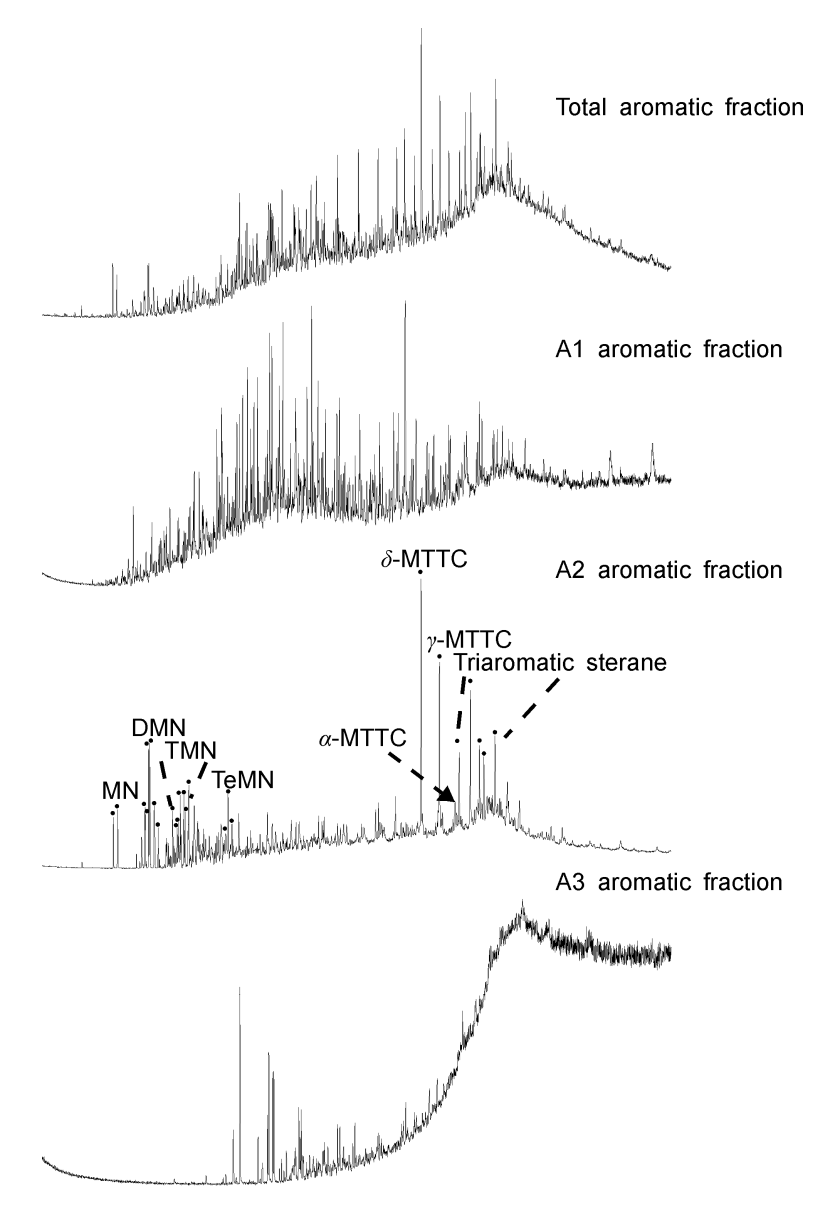

Figure 1 Total ion chromatogram (TIC) of the total aromatic fraction, A1 aromatic sub-fraction, A2 aromatic sub-fraction and A3 aromatic subfraction. MN, methyl-naphthalene; DMN, dimethyl-naphthalene; TMN, trimethyl-naphthalene; TeMN, tetramethyl-naphthalene.

samples. The aromatic fraction comprises long-chain alkylbenzenes (including long-chain alkyltoluenes), aryl isoprenoids, methylated naphthalenes and phenanthrenes, aromatic steroids, MTTC compounds and others. There is a large variation in the relative abundances of different groups of aromatic hydrocarbons in the sample profile (Figure 3), and this reflects the dynamics of the depositional environments and biological inputs. For example, the variations in the relative abundances of long-chain alkylbenzenes in the source rocks may indicate changes in the productivity of halophiles [6] and other brackish water plankton [20]. The detection of aryl isoprenoids suggests the presence of photosynthetic sulfur bacteria, and the occurrence of euxinic conditions in the photic zone of water body [21-24]. Abnormally high abundances of long-chain alkylbenzenes were detected in CDM1. The MTTC compounds, longchain alkylbenzenes, and aryl isoprenoids are all relatively abundant in CDM3, CDM4, and CDM5, and in CDM4, there is also an enrichment of the naphthalenes and phenanthrenes. In CDM2 and CDM6, the naphthalenes and phenanthrenes are a major contributor to the aromatic fractions, and there are also abundant MTTCs, but the lowest relative abundance of long-chain alkylbenzenes and aryl isoprenoids. These results indicate that, in CDM2 and CDM6, there are relatively low contributions from halophiles, brackish water algae, and photosynthetic sulfur bacteria to sedimentary organic matter. However, the relatively high abundances of MTTCs in these two samples suggests that the hypothesis that MTTCs are sourced from halophiles, brackish water algae, or photosynthetic sulfur bacteria is less plausible.

The relative abundances and distributions of different MTTC compounds in the aromatic fractions change significantly through the depth profile. For example, the $\alpha$ MTTC/ $\delta$-MTTC ratio, an indicator of the paleosalinity of a water body, is higher in CDM3, CDM4 and CDM5 than that in CDM6, CDM1 and CDM 2 (Table 2), reflecting the changes in the aquatic environment during the development of the source rock. The gammacerane index is regarded as a good biomarker of water column stratification [25-27]. As shown in Figure 4 , the $\alpha$-MTTC $/ \delta$-MTTC values correlate well with the gammacerane index $\left(R^{2}=0.83\right)$ for all samples except CDM5, indicating that water column stratification affects the distributions of different MTTC compounds. When the water column is strongly stratified, the hypersaline bottom water does not easily mix with the upper water column, resulting in lower salinity of the upper water body. This may provide a suitable environment for the production of $\alpha$-MTTC by organisms. This speculation is supported by a previous report that suggested that MTTCs are derived from the upper water body [6]. The Messinian evaporitic in Italy was deposited in a hypersaline water body, but the MTTC compounds are dominated by $\alpha$-MTTC. This suggests a low salinity in the upper water column [26] that may be not mixed well with the hypersaline bottom water because of strong water column stratification. Our results provide further evidence that water column stratification has an importance influence on the distribution of MTTC compounds. Only exception is that in CDM5, the $\alpha$-MTTC $/ \delta$-MTTC value was high but the gammacerane index is not as high as expected. This sample is characterized by extremely high abundances of anhydrite (Table 1), indicating the growing salinity of the water body, which may be not suitable for the survival of ciliates which are the biological sources of gammacerane [25].

\subsection{Comparison of stable carbon isotope compositions of MTTC compounds with other biomarkers}

The stable carbon isotope compositions of the MTTC compounds and saturated hydrocarbon biomarkers are listed in Table 3. As shown in Figure 5, the same carbon isotope values occur for the different carbon number MTTC compounds in each sample, usually with a difference of lower than $1 \%$ o. Similar phenomena have also been reported for MTTC compounds in other zones, such as in the oils sourced from the Jizhong Depression and the source rocks of the Jianghan Basin in China [11,13], the limestones of 

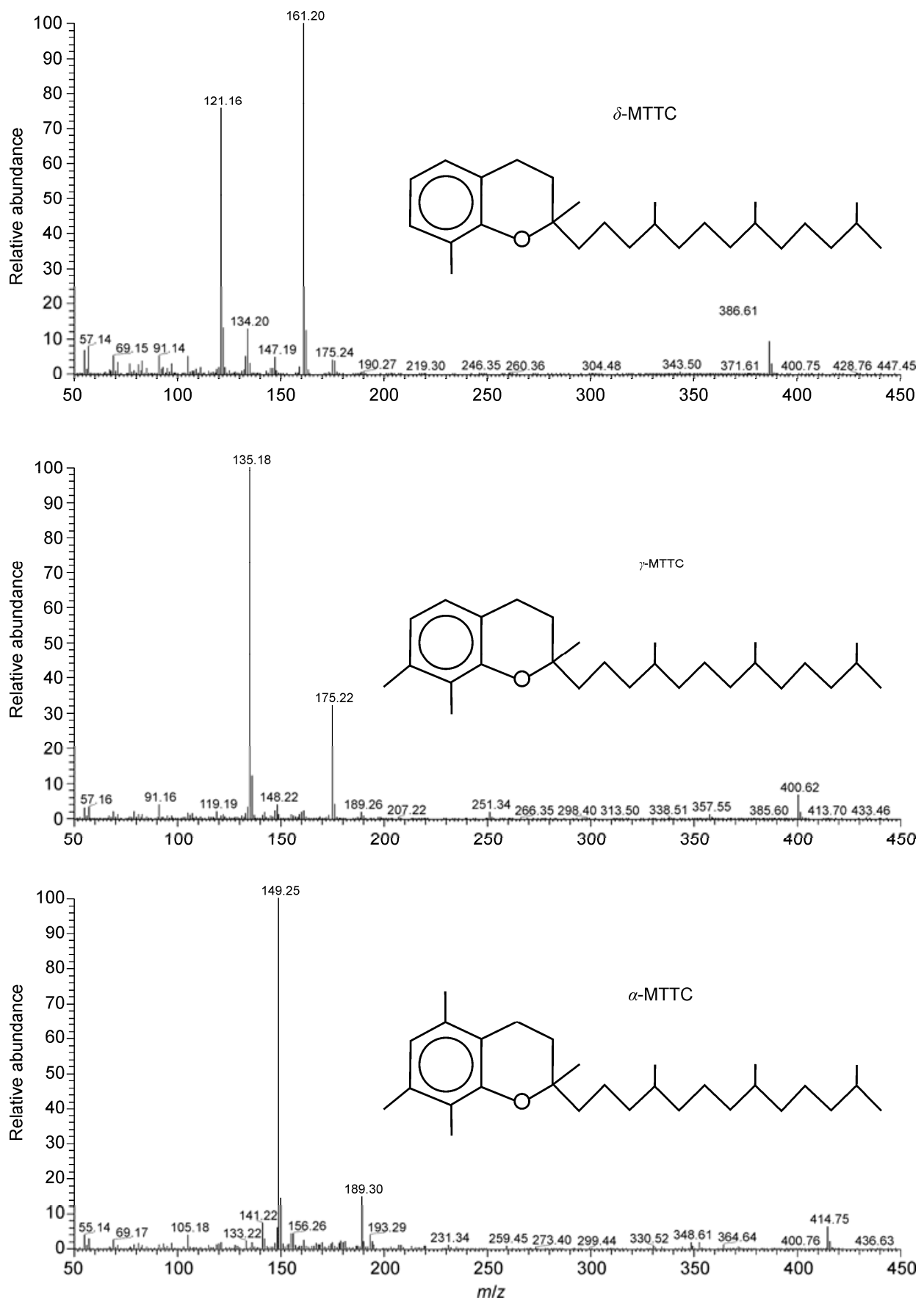

Figure 2 Mass spectrum and chemical structure of three main MTTC compounds.

north Jura in France [14], the Miocene marl in the northern Appenines in Italy [28], and the Miocene/Pliocene sediments from the Sdom Formation, Dead Sea in Israel [29]. The similar carbon isotope values of the different carbon number MTTC compounds may indicate the same biological precursors for these compounds.

Tocopherol and archaea are known to be sources of pristane and phytane, respectively [30,31], although the phytyl side chains of chlorophyll a in phototrophic organisms are usually the most important source of these two compounds [27]. In each sample from the studied area, the carbon isotope values for pristane typically differ by less than $1 \%$ from phytane. The slight enrichment of ${ }^{13} \mathrm{C}$ in phytane can be explained by extra contributions from halophilic archaea to phytane [11]. Halophilic archaea can use primary organic matter as a carbon source. During biological processes, the halophilic archaea may produce phytane leading to a slight enrichment in the ${ }^{13} \mathrm{C}$ values for phytane relative to the primary producer derived pristane. However, overall the carbon isotope compositions of pristane and phytane are consistent with both compounds being sourced from phototrophic primary producers. As shown in Figure 6(c) 

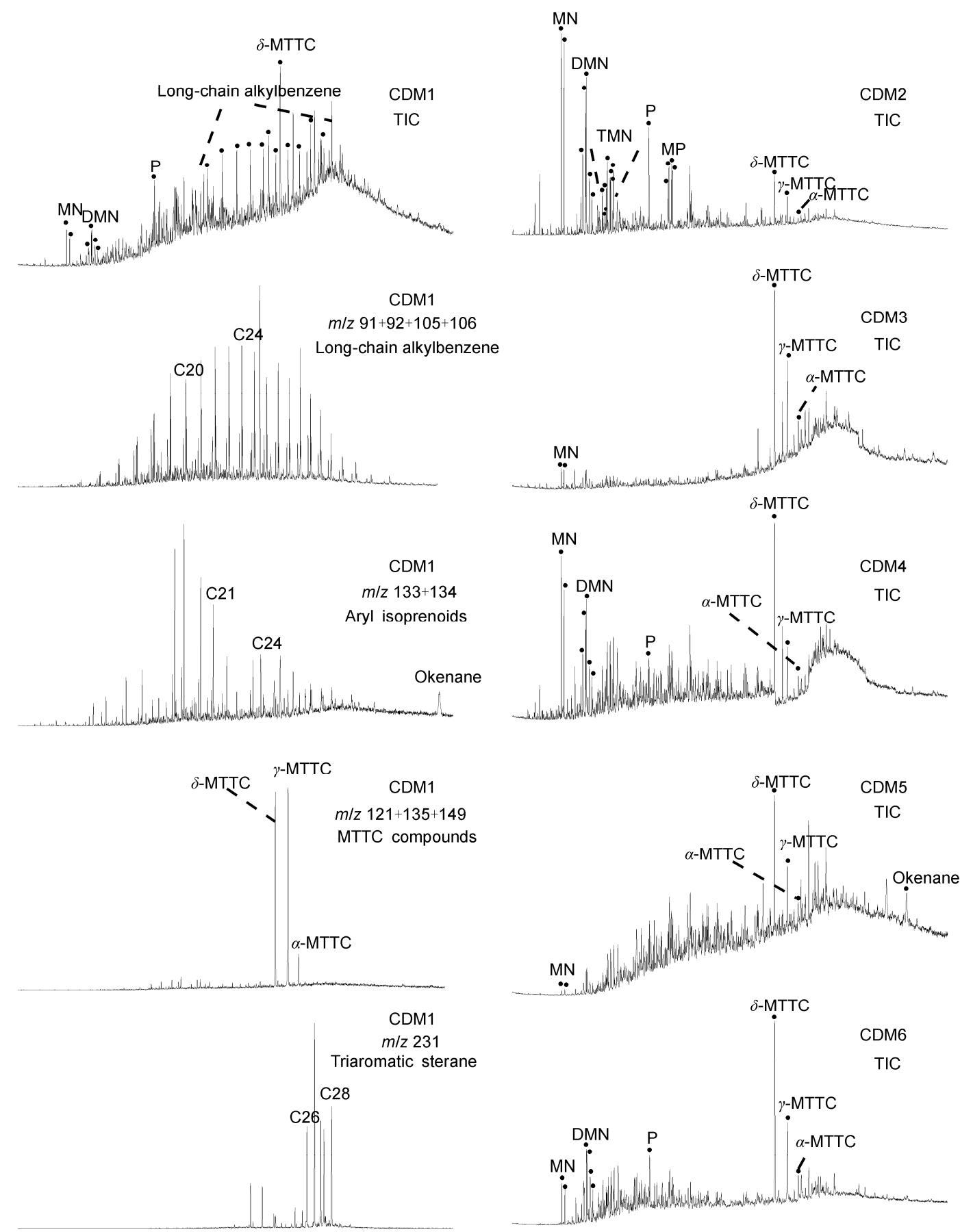

Figure 3 Main groups of aromatic compounds in CDM1 and total ion chromatogram (TIC) of the total aromatic fraction of samples. MN, Methylnaphthalene; DMN, dimethyl-naphthalene; TMN, trimethyl-naphthalene; P, phenanthrene; MP, methyl-phenanthrene.

and (e), the MTTC compounds have almost the same carbon isotope values as pristane and phytane, which is consistent with previous studies [11,13,14,28,29]. For example, the MTTC compounds in Miocene marl in the northern Appenines, Italy, were abnormally enriched with ${ }^{13} \mathrm{C}$, and ${ }^{13} \mathrm{C}$-enriched pristane, phytane and other photosynthetic primary producer derived biomarkers were also detected in these samples. The extremely high $\delta^{13} \mathrm{C}$ values of primary producer-derived biomarkers were interpreted to result from a localized $\mathrm{CO}_{2}$-limited ecosystem. Relatively low $\mathrm{CO}_{2}$ concentration in a water body leads to the decreasing fractionation of ${ }^{13} \mathrm{C}$ in autotrophic organisms [28], resulting in the enrichment of ${ }^{13} \mathrm{C}$ in MTTC compounds and other primary producer-derived biomarkers. Therefore, results suggest that the MTTC compounds could be sourced from photosynthetic primary producers.

The distribution of steroids in sedimentary organic matter can be a good marker of the contribution of primary 
Table 2 Molecular parameters calculated from the studied samples ${ }^{\text {a) }}$

\begin{tabular}{|c|c|c|c|c|c|c|c|}
\hline Sample No. & $\mathrm{Pr} / \mathrm{Ph}$ & GI & $\mathrm{C}_{29} \mathrm{~S} / \mathrm{S}+\mathrm{R}$ & Hopane/Sterane & $\alpha / \delta$-MTTC $^{\mathrm{e})}$ & $\alpha / \gamma$-MTTC & $\gamma / \delta$-MTTC \\
\hline CDM1 & 0.29 & 0.54 & 0.22 & 0.18 & 0.15 & 0.21 & 0.71 \\
\hline CDM2 & 0.37 & 0.88 & 0.17 & 0.15 & 0.18 & 0.27 & 0.65 \\
\hline CDM3 & 0.23 & 0.9 & 0.19 & 0.11 & 0.21 & 0.46 & 0.46 \\
\hline CDM4 & 0.24 & 1.4 & 0.16 & 0.08 & 0.23 & 0.48 & 0.48 \\
\hline CDM5 & 0.29 & 0.64 & 0.29 & 0.25 & 0.27 & 0.58 & 0.46 \\
\hline
\end{tabular}

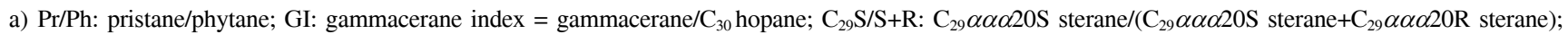
Hopane/Sterane: the sum of $\mathrm{C}_{29}$ to $\mathrm{C}_{35}$ hopane divided by the sum of regular $\mathrm{C}_{27}$ to $\mathrm{C}_{29}$ sterane $=\left(\mathrm{C}_{29}+\mathrm{C}_{30}+\mathrm{C}_{31} \alpha \beta 22 \mathrm{~S}+\mathrm{C}_{31} \alpha \beta 22 \mathrm{R}+\mathrm{C}_{32} \alpha \beta 22 \mathrm{~S}+\mathrm{C}_{32} \alpha \beta 22 \mathrm{R}+\right.$ $\left.\mathrm{C}_{33} \alpha \beta 22 \mathrm{~S}+\mathrm{C}_{33} \alpha \beta 22 \mathrm{R}+\mathrm{C}_{34} \alpha \beta 22 \mathrm{~S}+\mathrm{C}_{34} \alpha \beta 22 \mathrm{R}+\mathrm{C}_{35} \alpha \beta 22 \mathrm{~S}+\mathrm{C}_{35} \alpha \beta 22 \mathrm{R}\right)$ hopanes $\left(\mathrm{C}_{27} \alpha \alpha \alpha 20 \mathrm{R}+\mathrm{C}_{27} \alpha \alpha \alpha 20 \mathrm{~S}+\mathrm{C}_{27} \alpha \beta \beta 20 \mathrm{R}+\mathrm{C}_{27} \alpha \beta \beta 20 \mathrm{~S}+\mathrm{C}_{28} \alpha \alpha \alpha 20 \mathrm{R}+\mathrm{C}_{28} \alpha \alpha \alpha 20 \mathrm{~S}+\right.$ $\left.\mathrm{C}_{28} \alpha \beta \beta 20 \mathrm{R}+\mathrm{C}_{28} \alpha \beta \beta 20 \mathrm{~S}+\mathrm{C}_{29} \alpha \alpha \alpha 20 \mathrm{R}+\mathrm{C}_{29} \alpha \alpha \alpha 20 \mathrm{~S}+\mathrm{C}_{29} \alpha \beta \beta 20 \mathrm{R}+\mathrm{C}_{29} \alpha \beta \beta 20 \mathrm{~S}\right)$ steranes; $\alpha / \delta$-MTTC $=\alpha-\mathrm{MTTC} / \delta$-MTTC; $\alpha / \gamma-\mathrm{MTTC}=\alpha-\mathrm{MTTC} / \gamma-\mathrm{MTTC}$; $\gamma / \delta$-MTTC $=\gamma$-MTTC $/ \delta$-MTTC.

Table 3 Stable carbon isotope compositions of MTTC compounds and other biomarkers in source rocks (\%o, VPDB)

\begin{tabular}{|c|c|c|c|c|c|c|c|c|}
\hline Sample No. & Pristane & Phytane & $\mathrm{C}_{27} \alpha \alpha \alpha 20$ Rsterane & $\mathrm{C}_{28} \alpha \alpha \alpha 20$ Rsterane & $\mathrm{C}_{29} \alpha \alpha \alpha 20$ Rsterane & $\delta$-MTTC & $\gamma$-MTTC & $\alpha$-MTTC \\
\hline CDM1 & $-26.6 \pm 0.6$ & $-25.3 \pm 0.3$ & $-25.0 \pm 0.3$ & $-26.7 \pm 0.1$ & $-23.9 \pm 0.3$ & $-26.0 \pm 0.1$ & $-27.0 \pm 0.1$ & \\
\hline CDM2 & $-26.6 \pm 0.2$ & $-25.7 \pm 0.2$ & $-23.5 \pm 0.1$ & $-26.2 \pm 0.1$ & $-24.8 \pm 0.0$ & $-25.8 \pm 0.2$ & $-26.1 \pm 0.2$ & \\
\hline CDM4 & $-26.7 \pm 0.4$ & $-25.7 \pm 0.3$ & $-25.4 \pm 0.4$ & $-27.1 \pm 0.2$ & $-25.5 \pm 0.1$ & $-27.5 \pm 0.1$ & $-27.7 \pm 0.2$ & $-27.0 \pm 0.1$ \\
\hline CDM5 & $-26.4 \pm 0.2$ & $-26.3 \pm 0.0$ & $-25.0 \pm 0.1$ & $-26.9 \pm 0.3$ & $-25.8 \pm 0.1$ & $-27.2 \pm 0.0$ & $-27.1 \pm 0.5$ & $-27.1 \pm 0.5$ \\
\hline CDM6 & $-24.5 \pm 0.3$ & $-23.6 \pm 0.3$ & $-23.8 \pm 0.1$ & $-26.6 \pm 0.4$ & $-23.7 \pm 0.3$ & $-25.1 \pm 0.3$ & $-25.5 \pm 0.2$ & \\
\hline
\end{tabular}

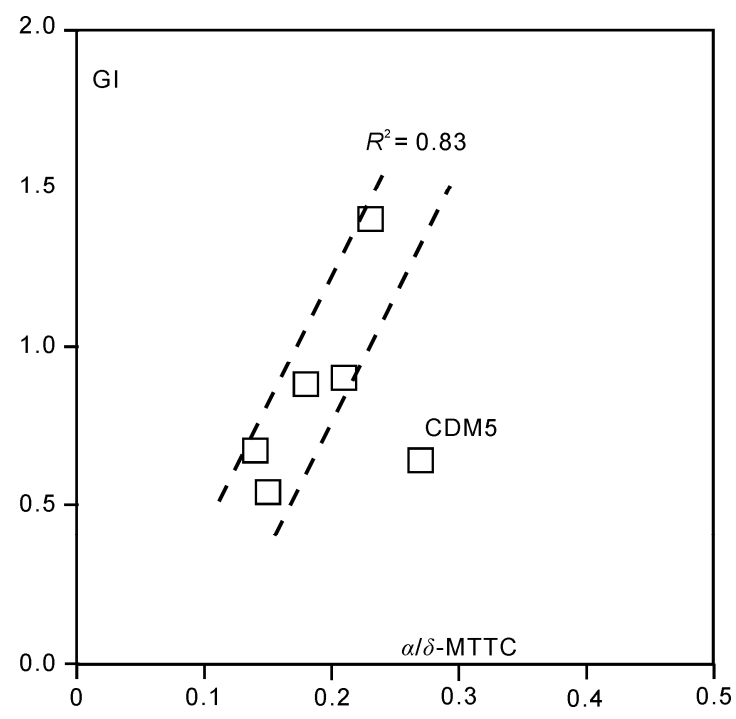

Figure 4 Relationships between gammacerane index (GI) and $\alpha / \delta$ MTTC values in extracts of the source rocks.

producers. Typically, the $\mathrm{C}_{27}$ steranes are considered to be sourced from algae and other plankton, $\mathrm{C}_{29}$ steranes are sourced from algae or higher plants, and the $\mathrm{C}_{28}$ steranes are related to specific algae inputs, such as diatoms, coccolithophores, and dinoflagellates [27,32-35]. The very similar carbon isotope values for the $\mathrm{C}_{29}$ and $\mathrm{C}_{27}$ steranes, and the very low contribution of higher plants to sedimentary organic matter in the studied samples [16], indicate that algae are the main source of the steroids. The stable carbon

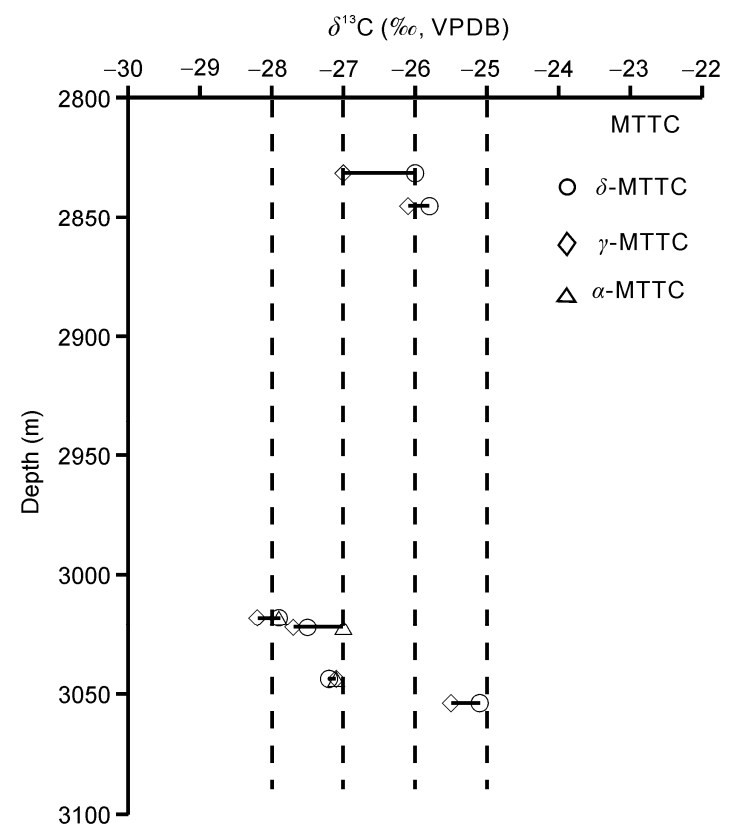

Figure 5 Carbon isotope values of MTTC compounds in source rocks extracts.

isotope compositions of the MTTC compounds and steranes are plotted in Figure 6(b),(d),(f). In general, the carbon isotope values of the $\mathrm{C}_{28}$ sterane are very similar to the MTTC compounds (Figure 6(d)), while the carbon isotope values for the $\mathrm{C}_{29}$ and $\mathrm{C}_{27}$ sterane are enriched in ${ }^{13} \mathrm{C}$ by about $2 \%$ o relative to the MTTC compounds (Figure 6(b),(f)). In the Fushun oil shale of China, the $\mathrm{C}_{27}$ sterane was enriched in 

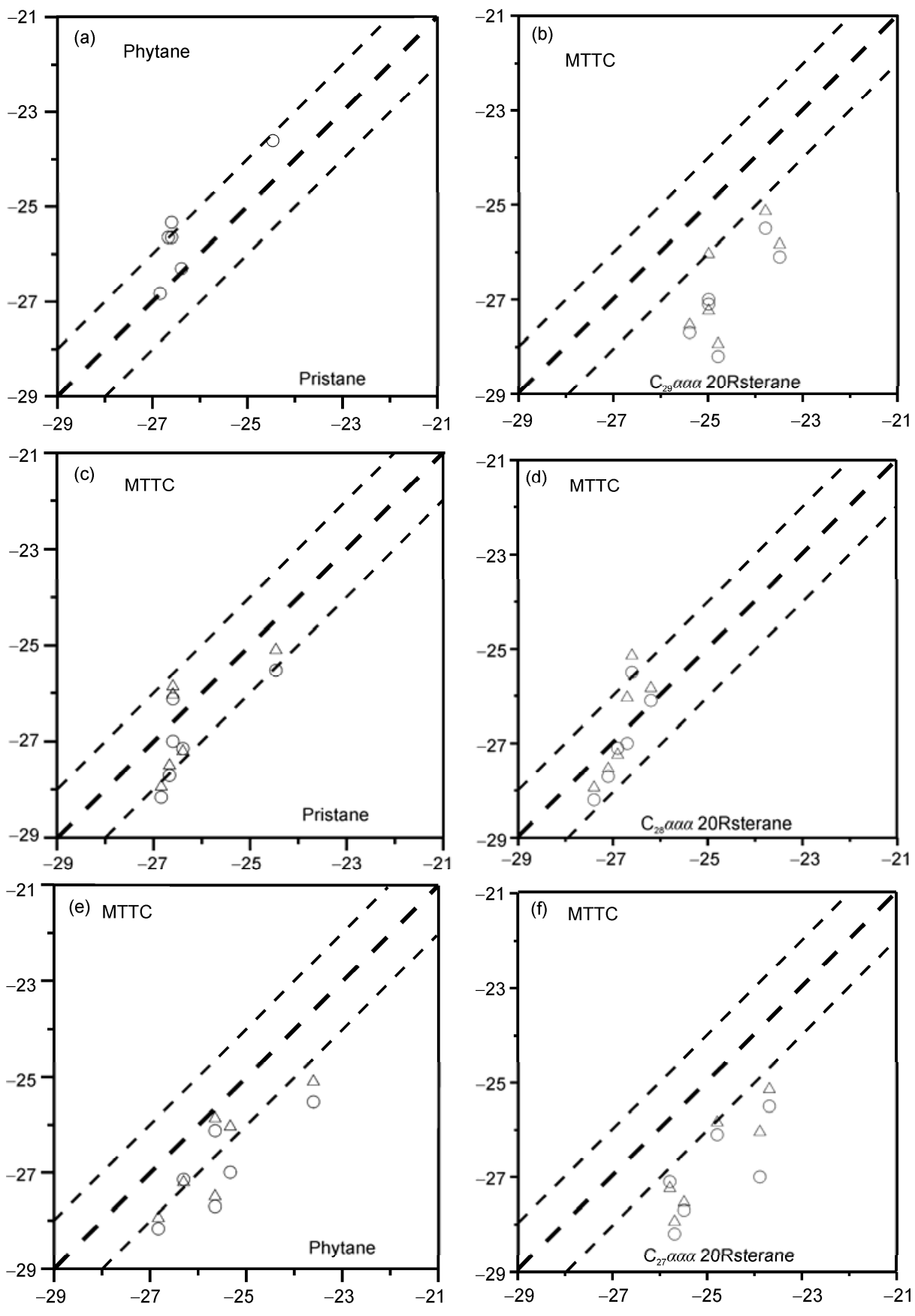

$\triangle \delta$-MTTC

O $\gamma$-MTTC

Figure 6 Comparison of the carbon isotope values (\%, VPDB) between pristane and phytane, and between the MTTC compounds and pristane, phytane, and steranes.

${ }^{13} \mathrm{C}$ relative to the $\mathrm{C}_{28}$ sterane by $3 \%$ and this was attributed to source difference (e.g. dinoflagellate source for the $\mathrm{C}_{27}$ sterane and other algae source for the $\mathrm{C}_{28}$ sterane) [35]. The depletion of ${ }^{13} \mathrm{C}$ in $\mathrm{C}_{28}$ sterane relative to $\mathrm{C}_{29}$ and $\mathrm{C}_{27}$ steranes by $0.5 \%$ to $3.1 \%$ has also been found in modern saline meromictic lake, which was considered to be related to the specific algae sources for the $\mathrm{C}_{28}$ sterane [36]. Consequently, we speculated that the MTTC compounds may be sourced from algae with specific niches.

\subsection{Biological sources of MTTC compounds and implication for the depositional environments}

It is generally accepted that algae and bacteria are the main sources of sedimentary organic matter in saline lacustrine settings [13], with small contributions from higher plants [37]. A previous study identified that algaes are also main sources of sedimentary organic matter in our samples, with little input from higher plants [16]. Photosynthetic bacteria 
can also be a biological source of MTTC compounds [14]. Because of the similar carbon isotope compositions of the MTTC compounds and $\mathrm{C}_{28}$ sterane, and the high abundances of MTTC compounds and low hopane/sterane ratios (lower than 0.25), photosynthetic bacteria can be excluded as a main biological sources of MTTC compounds.

Theoretically, the carbon isotope compositions of primary biomass are controlled by the ${ }^{13} \mathrm{C}$ content of the carbon sources, and isotope effects associated with the assimilation of carbon [38,39]. The effects of biological sources on the stable carbon isotope compositions of organic molecules in sediments have been widely documented [40,41]. However, in saline lacustrine deposits, the stable carbon isotope compositions of primary biomass are also controlled by the water salinity $[42,43]$. Algaes are important primary producers in saline lacustrine ecosystems, and are also the main biological sources of steroids in sedimentary organic matter. Therefore, differences in the stable carbon isotope compositions of steroids can be related to the different algae sources, and possibly, to the different niches occupied by these algaes. In the Fushun oil shale in China, the different carbon isotope compositions in $\mathrm{C}_{27}$ and $\mathrm{C}_{28}$ steranes are related to different algae sources. Schouten et al. [36] found that $\mathrm{C}_{28}$ sterane was depleted in ${ }^{13} \mathrm{C}$ relative to other steranes in a modern saline meromictic lake, and they suggested that microalgaes in the lake showed distinct vertical zonation, and experienced slightly different environmental regimes, light intensities, and growth rates. Thus, the organic matters produced by these microalgaes have different carbon isotope characteristics. The depletion of ${ }^{13} \mathrm{C}$ in $\mathrm{C}_{28}$ sterane relative to $\mathrm{C}_{27}$ and $\mathrm{C}_{29}$ sterane in this study may be also due to the different algaes sources of steroids. The different algae occupy different water column niches, with distinct $\mathrm{CO}_{2}$ concentrations, nutrients abundances, light intensities, and other environmental factors. The combination of these factors leads to variable carbon isotope fractionation associated with carbon assimilation by primary producers, resulting in different carbon isotope compositions in organic matters produced by these algaes. As discussed previously, MTTC compounds are sourced from primary producers. The extremely similar carbon isotope compositions between the MTTC compounds and $\mathrm{C}_{28}$ sterane suggests that the MTTC compounds may be produced by microalgae within specific niches, and these niches are probably situated at the base of the photo zone $[44,45]$ where high concentrations of $\mathrm{CO}_{2}$ should be expected [45]. Regionally, a hot and dry climate occurred during the development of the source rocks in this study [15], which could lead to large temperature gradients between the water surface and the base of the photo zone, with more $\mathrm{CO}_{2}$ likely to be dissolved in the cold water at the base of the photo zone [46]. High concentrations of $\mathrm{CO}_{2}$ can decrease the carbon isotope fractionation during carbon assimilation by primary biomass, resulting in the ${ }^{13} \mathrm{C}$ depleted MTTC compounds that may be produced by the microalgaes in this niche. Sinninghe Damsté et al. [2] ini- tially thought the $\delta$-MTTC-producing biomass was located in the bottom water with salt leaking from the sediments, and, consequently, the non photosynthetic bacteria were ascribed as the biological sources of MTTC. As shown in Figure 4 , the $\alpha$-MTTC/ $\delta$-MTTC values are closely correlated with the gammacerane index, which indicates the influence of water column stratification on the distributions of various MTTC compounds. When the water column stratification is not well developed, the hypersaline bottom water will mix with the upper water column, resulting in lots of $\delta$-MTTC and $\gamma$-MTTC being produced by microalgaes. On the contrary, these microalgaes will produce much more $\alpha$-MTTC. Because the bottom layers of the upper water column are more easily influenced by the hypersaline bottom water relative to the top layer of the upper water column, the MTTC-producing microalgaes may thrive in the base layer of the upper water column.

Throughout the core depth profile, the gammacerane index is high from CDM5 to CDM3, which is indicative of strong water column stratification, with relatively little influence from the hypersaline bottom water on the upper water column. The relatively low salinity of the upper water column during the deposition of these samples is suitable for the increased production of $\alpha$-MTTC by microalgae relative to $\delta$-MTTC. In the same samples, pristane, phytane, MTTC compounds, and $\mathrm{C}_{27}$ and $\mathrm{C}_{29}$ sterane are all depleted in ${ }^{13} \mathrm{C}$ relative to the same compounds in the other three samples. This is consistent with the relative enrichment of ${ }^{12} \mathrm{C}$ in biomass in a low water salinity environment [43] and it is strong evidence that water salinity significantly influences the stable carbon isotope compositions of primary biomass.

\section{Conclusions}

The MTTC compounds were successfully separated and enriched from the aromatic fractions of organic matter using a newly developed two-step column chromatography methods. In this process, most of the UCM compounds were removed from the aromatic sub-fraction which contained the MTTC compounds, resulting in the accurate determination of the stable carbon isotope compositions of MTTC compounds. By comparing the stable carbon isotope compositions of the MTTC compounds with pristane, phytane, and steroids in a group of samples, algae appear to be the main source of the MTTC compounds. The similar carbon isotope compositions for $\delta$-MTTC, $\gamma$-MTTC, and $\alpha$-MTTC in any given sample, together with the published carbon isotope values for MTTC compounds in other environmental setting, indicate that the three different carbon number MTTC compounds may share the same biological sources. These sources could be specific microalgae, while the distribution partners of these three MTTC compounds are controlled mainly by the salinity of water body. 
We appreciate the assistance of two anonymous reviewers and an invited editor for their thorough and constructive reviews, which greatly improved the clarity and quality of this article. Many thanks go to Dr. Zhang Xiaobao for providing the source rocks. This work was supported by the National Natural Science Foundation of China (40972093), the National Special Program of Oil and Gas in China (2011ZX05008-002), the Natural Science Foundation of Zhejiang Province (R5080124) and the Fundamental Research Funds for the Central Universities. This is contribution No. IS-1403 from GIGCAS.

1 Sinninghe Damsté J S, Ten Haven H L, De Leeuw J W, et al. Organic geochemical studies of a Messinian evaporitic basin, northern Apennines (Italy). II: Isoprenoid and $n$-alkyl thiophenes and thiolanes. Org Geochem, 1986, 10: 791-805

2 Sinninghe Damsté J S, Kock-van Dalen A C, De Leeuw J W, et al. The identification of mono-, di- and trimethyl 2-methyl-2-(4,8,12trimethyltridecyl) chromans and their occurrence in the geosphere. Geochim Cosmochim Acta, 1987, 51: 2393-2400

3 Zhang S, Huang R, Yu X. The distributions of MTTC compounds in sedimentary organic matters of saline lacustrine basin (in Chinese). Acta Sedimentol Sin, 1990, 8: 57-64

4 Zhu Y, Weng H, Su A, et al. Geochemical characteristics of Tertiary saline lacustrine oils in the Western Qaidam Basin, northwest China. Appl Geochem, 2005, 20: 1875-1889

5 De Leeuw J W, Sinninghe Damsté J S. Organic sulfur compounds and other biomarkers as indicators of palaeosalinity. In: Orr W L, White C M, eds. Geochemistry of Sulfur in Fossil Fuels. Washington, D C: American Chemical Society, 1990. 417-443

6 Sinninghe Damsté J S, Keely B J, Betts S E, et al. Variations in abundances and distributions of isoprenoid chromans and long-chain alkylbenzenes in sediments of the Mulhouse Basin: A molecular sedimentary record of palaeosalinity. Org Geochem, 1993, 20: 12011215

7 Schwark L, Vliex M, Schaeffer P. Geochemical characterization of Malm Zeta laminated carbonates from the Franconian Alb, SWGermany (II). Org Geochem, 1998, 29: 1921-1952

8 Li M, Larter S R, Taylor P, et al. Biomarkers or not biomarkers? A new hypothesis for the origin of pristane involving derivation from methyltrimethyltridecylchromans (MTTCs) formed during diagenesis from chlorophyll and alkylphenols. Org Geochem, 1995, 23: 159167

9 Sinninghe Damsté J S, De Leeuw J W. Comments on "Biomarkers or not biomarkers. A new hypothesis for the origin of pristane involving derivation from methyltrimethyltridecylchromans (MTTCs) formed during diagenesis from chlorophyll and alkylphenols" from M. Li, S. R. Larter, P. Taylor, D. M. Jones, B. Bowler and M. Bjorøy. Org Geochem, 1995, 23: 1085-1087

10 Barakat A O, Rullkötter J. A comparative study of molecular paleosalinity indicators: Chromans, tocopherols and $\mathrm{C}_{20}$ isoprenoid thiophenes in Miocene lake sediments (Nordlinger Ries, Southern German). Aquat Geochem, 1997, 3: 169-190

11 Grice K, Schouten S, Peters K E, et al. Molecular isotopic characterisation of hydrocarbon biomarkers in Palaeocene-Eocene evaporitic, lacustrine source rocks from the Jianghan Basin, China. Org Geochem, 1998, 29: 1745-1764

12 Grice K, Schouten S, Nissenbaum A. A remarkable paradox: Sulfurised freshwater algal (Botryococcus braunii) lipids in an ancient hypersaline euxinic ecosystem. Org Geochem, 1998, 28: 195-216

13 Lu H, Hou L, Chen T, et al. Stable carbon isotopic compositions of methylated-MTTC in crude oils from saline lacustrine depositional environment: source implications. Acta Geol Sin, 2007, 81: 10411048

14 Van Kaam-Peters H M E, Sinninghe Damsté J S. Characterisation of an extremely organic sulphur-rich, 150 Ma old carbonaceous rock: Palaeoenvironmental implications. Org Geochem, 1997, 27: 371-397

15 Peng D H. Geology, geochemical characteristics and mechanism of hydrocarbon generating for source rocks from the Tertiary salty lacustrine facies in the West Region of the Qaidam Basin (in Chinese).
Dissertation for the Doctoral Degree. Guangzhou: Guangzhou Institute of Geochemistry, Chinese Academy of Sciences, 2004. 1-77

16 Zhang Y, Sun Y, Xie L, et al. The occurrence and significance of $\mathrm{C}_{25} \mathrm{HBI}$ in Cenozoic saline lacustrine source rocks from the Western Qaidam Basin, NW China. Chin Sci Bull, 2011, 56: 1390-1398

17 Pan C, Zhang M, Peng D, et al. Confined pyrolysis of Tertiary lacustrine source rocks in the Western Qaidam Basin, Northwest China: Implications for generative potential and oil maturity evaluation. Appl Geochem, 2010, 25: 276-287

18 Zhou P, Sun Y. Rapid separation of alkylated naphthalenes in crude oils by column chromatography and its elementary application (in Chinese). Geochimica, 2008, 37: 512-518

19 Sheng G, Fu J, Jiang J, et al. Discovery of dehydroxytocopherol in crude oils and source rock, and its significance. Sci China Ser B, 1987, 30: 1338-1344

20 Zhou W, Wu Q, Wang R, et al. Distribution of aromatic biomarkers in pyrolysates of coccolithophore. Chin Sci Bull, 2001, 46: 246- 252

21 Zhang C, Zhang Y, Cai C. Aromatic isoprenoids from the 25-65 Ma saline lacustrine formations in the western Qaidam Basin, NW China. Org Geochem, 2011, 42: 851-855

22 Brocks J J, Schaeffer P. Okenane, a biomarker for purple sulfur bacteria (Chromatiaceae), and other new carotenoid derivatives from the 1640 Ma Barney Creek Formation. Geochim Cosmochim Acta, 2008, 72: 1396-1414

23 Sun Y, Xu S, Lu H, et al. Source facies of the Paleozoic petroleum systems in the Tabei uplift, Tarim Basin, NW China: Implications from aryl isoprenoids in crude oils. Org Geochem, 2003, 34: 629634

24 Summons R E, Powell T G. Chlorobiaceae in Palaeozoic seas revealed by biological markers, isotopes and geology. Nature, 1986, 319: 763-765

25 Sinninghe Damsté J S, Kenig F, Koopmans M P, et al. Evidence for gammacerane as an indicator of water column stratification. Geochim Cosmochim Acta, 1995, 59: 1895-1900

26 Kenig F, Sinninghe Damsté J S, Frewin N L, et al. Molecular indicators for palaeoenvironmental change in a Messinian evaporitic sequence (Vena del Gesso, Italy). II: High-resolution variations in abundances and ${ }^{13} \mathrm{C}$ contents of free and sulphur-bound carbon skeletons in a single marl bed. Org Geochem, 1995, 23: 485-526

27 Peters K E, Walters C C, Moldowan J M. The Biomarker Guide. 2nd ed. Cambridge: Cambridge University Press, 2005

28 Schouten S, Hartgers W A, Lòpez J F, et al. A molecular isotopic study of ${ }^{13} \mathrm{C}$-enriched organic matter in evaporitic deposits: Recognition of $\mathrm{CO}_{2}$-limited ecosystems. Org Geochem, 2001, 32: 277-286

29 Grice K, Schouten S, Nissenbaum A. Isotopically heavy carbon in the $\mathrm{C}_{21}$ to $\mathrm{C}_{25}$ regular isoprenoids in halite-rich deposits from the Sdom Formation, Dead Sea Basin, Israel. Org Geochem, 1998, 28: 349-359

30 Goossens H, De Leeuw J W, Schenck L, et al. Tocopherols as likely precursor of pristane in ancient sediments and crude oils. Nature, 1984, 312: 440-442

31 Ten Haven H L, De Leeuw J W, Rullkötter J, et al. Restricted utility of the pristane/phytane ratio as a palaeoenvironmental indicator. Nature, 1987, 330: 641-643

32 Duan Y, Wen Q, Zheng G, et al. Carbon isotopic study of individual alcohol compounds in modern sediments from Nansha Islands sea area, China. Sci China Ser D-Earth Sci, 1997, 40: 491-495

33 Duan Y, Wang Z. Evidence from carbon isotope measurements for biological origins of individual long-chain $n$-alkanes in sediments from the Nansha Sea, China. Chin Sci Bull, 2002, 47: 578-581

34 Grantham P J, Wakefield L L. Variations in the sterane carbon number distributions of marine source rock derived crude oils through geological time. Org Geochem, 1988, 12: 61-73

35 Duan Y, Wu B, Zheng G, et al. The specific carbon isotopic compositions of branched and cyclic hydrocarbons from Fushun oil shale. Chin Sci Bull, 2004, 49: 369-373

36 Schouten S, Rijpstra W I C, Kok M, et al. Molecular organic tracers of biogeochemical processes in a saline meromictic lake. Geochim Cosmochim Acta, 2001, 65: 1629-1640

37 Bao J, Zhu C, Ma A. The relationship between methylated chromans 
and maturity of organic matter in the source rocks from Jianghan hypersaline basin. Sci China Ser D-Earth Sci, 2009, 52(Suppl 1): 34-41

38 Hayes J M. Factors controlling ${ }^{13} \mathrm{C}$ contents of sedimentary organic compounds: Principles and evidence. Mar Geol, 1993, 113: 111-125

39 Hayes J M, Freeman K H, Popp B N, et al. Compound-specific isotopic analyses: A novel tool for reconstruction of ancient biogeochemical processes. Org Geochem, 1990, 16: 1115-1128

40 Duan Y, Song J, Zhang H. Carbon isotopic studies of individual lipids in organisms from the Nansha Sea area, China. Sci China Ser D-Earth Sci, 2004, 47: 593-598

41 Duan Y, Zhang H, Zheng C, et al. Carbon isotopic characteristics and their genetic relationships for individual lipids in plants and sediments from a marsh sedimentary environment. Sci China Ser D-Earth Sci, 2005, 48: 1203-1210
42 Duan Y, Zhang H, Wu B, et al. Carbon isotopic studies of individual n-alkanes in crude oils from Qaidam Basin (in Chinese). J Mineral Petrol, 2003, 23: 91-94

43 Duan Y, Peng D, Zhang X, et al. Main controlling factors and genetic types of carbon isotopic compositions for crude oils from Qaidam Basin, China (in Chinese). Acta Sedimentol Sin, 2003, 21: 355-359

44 Schoell M, Hwang R J, Carlson R M K, et al. Carbon isotopic composition of individual biomarkers in gilsonites. Org Geochem, 1994, 21: 673-683

45 Collister J W, Summons R E, Lichtfouse E, et al. An isotopic biogeochemical study of the Green River oil shale. Org Geochem, 1992, 19: 265-276

46 Schoell M, Schouten S, Sinninghe Damsté J S. A molecular organic carbon isotope record of Miocene climate changes. Science, 1994, 263: $1122-1125$

Open Access This article is distributed under the terms of the Creative Commons Attribution License which permits any use, distribution, and reproduction in any medium, provided the original author(s) and source are credited. 